\title{
Transforming identity discourses to promote local interests during municipal amalgamations
}

\author{
Kees Terlouw (i)
}

Published online: 16 June 2017

(C) The Author(s) 2017. This article is an open access publication

\begin{abstract}
This paper discusses the different ways in which local identities are used in two Dutch municipalities. Like all local administrations these Dutch municipalities have to deal with external forces by plotting their own course between closing-off and opening-up. Local identities are used not only for resisting external threats like municipal amalgamations, but also to attract external resources. It proved useful to distinguish between primary identity discourses based on the widely recognised dominant characteristics of the local community, and secondary identity discourses based on how communities within a municipality have over time learned to deal with these different primary local identities. During an amalgamation this secondary identity discourse disappears with the old municipality. The disappearance of the protective shield of a secondary identity discourse can threaten the underlying primary local identities, and can bring local identities into the centre of the local political debate. A perceived external threat frequently changes the character of these local identities. They can become more inward oriented, focus more on their historical roots and their differences with others; they 'thicken' into resistance identity discourses. In other cases the secondary identity discourse of a municipality is too weak and
\end{abstract}

K. Terlouw $(\bowtie)$

Department of Human Geography and Spatial Planning, Utrecht University, Utrecht, The Netherlands

e-mail: k.terlouw@uu.nl indistinct to support the primary local identities of its communities. Municipal amalgamation can then help to promote a new more attractive secondary, 'thin' regional identity discourse based on a selection of characteristics used in established primary local identity discourses.

Keywords Local identity - Municipalities · Amalgamation · Identity discourses

\section{Introduction}

This paper analyses how local identities are used by different stakeholders in local communities to promote their interests. It studies the development of different types of local identity discourses in two Dutch municipalities. Local identities are used not only in discourses focussing on resisting external threats like municipal amalgamations, but also in discourses aiming to attract external resources through municipal amalgamation. This paper analyses the backgrounds of this differential use of local identities.

The growing pressures on Dutch municipalities to amalgamate and to cooperate on economic policies has strengthened the use of local identities in political debates. The Dutch Ministry of the Interior is increasingly confronted by local politicians who use local identity as an argument to resist amalgamations 
and by other local politicians who refer to their local identity to demand government support for their initiatives to promote their competitiveness in cooperation with others (BZK 2013). Especially the claim by some local politicians that they cannot amalgamate with their neighbours because of their different local identities hampers central policies towards creating more effective large municipalities. The Dutch Ministry of the Interior has difficulties coping with these arguments based on local identities. The Dutch Ministry of the Interior therefore commissioned a study to explore the importance of local identities for local communities. This paper is based on this study. The full report is published in Dutch by the Ministry of the Interior and accessible through their website (Terlouw and Hogenstijn 2015).

This paper starts with a more general discussion on individual and collective identity. It discusses that identities are not fixed facts, but developing narratives which interpret the changing relations with the outside world. From this perspective we analysed how local identity discourses are used in the local politics in two Dutch amalgamated municipalities. The empirical part of this paper starts with a discussion on what characterises the local identity of their community according to our interviewees. This shows what binds them together and what sets them apart from others. How groups deal with their different appreciations of the dominant local identity discourse is discussed subsequently. Attention then shifts to how identity discourses can change during a municipal amalgamation. Our first case study discusses how a local dominant identity discourse focussing on local differences and incompatibility can be replaced after amalgamation by an identity discourse focussed on regional development through attracting external resources. Our second case study shows how different forms of external urbanisation threats are linked with different types of regional and local identity discourses. The conclusion discusses the wider implications of this diverse use of local and regional identity discourses.

\section{Identity discourses}

Before analysing the different ways in which local identities are used in these amalgamated municipalities, this section discusses some general aspects of identity. The reflexive character of identities is first discussed in relation to the importance of a biographical narrative for individual identities. This is used in the last part of this section to discuss how collective identities such as local identities are used in identity discourses. The next section discusses how local identities were measured in the two Dutch case studies.

All identities conceptualises which elements $(n-1)$ characterise an entity (n) and how it relates to others $(n+n)$. Individual identity gives meaning to the relation between the individual (n) and the communities to which it belongs $(n+1)$ in relation to the different character traits a person possesses $(n-1)$. Many regard identity as stable and determined by these characteristics and relations and that identities can be discovered by internal or external inquiry (Benwell and Stokoe 2006, 3). But identities are not fixed facts, but are changeable over time. Identity is not only about sameness and difference towards others, but also about dealing with change over time. Life's experiences shape and change an individual's identity, especially while an individual acquires new characteristics and has to deal with new challenges in its relations with others. Individuals acquire new characteristics $(n-1)$ during their lifetime and have to deal with new challenges from their environment $(n+1)$. Identity discourses can change the focus on specific individual characteristics $(n-1)$, the relation with others $(n+1)$, and key aspects of the past $(t-1)$ and of the future $(t+1)$. Individuals adapt their identity to make sense of the strained and changing relation between their individual uniqueness and their collective sameness. Individuals try to comprehend these frictions through the construction of a more or less coherent life narrative (n) which tries to make sense of their acquired characteristics $(n-1)$, their past $(t-1)$ and changing $(\mathrm{t}+1)$ relations with others $(\mathrm{n}+1)$ (Verhaeghe 2014).

Identities are not based on fixed facts, but based on narratives created, told, revised and retold throughout life (Benwell and Stokoe 2006, 4). These narratives are not only about the past and the present, but also about hope and fear for the future. Self-identities are based on life narratives about who I was, who I am, who I might become, but also about who I want to become and what I fear to become (Jaspal 2014, 6-7; Dixon et al. 2014, 271). "Self-identity is not a 
distinctive trait, or even a collection of traits, possessed by the individual. It is the self as reflexively understood by the person in terms of her or his biography." (Giddens 1991, 53). Identities have become less stable through the accelerating changes in modern society presenting everybody with an ever growing number opportunities and threats: "we have no choice but to choose" (Giddens 1991, 81). The growing diversity of options individuals and organisations are faced with in the current phase of 'high' or 'late' modernity forces people to make ever more deliberate choices. These increased freedoms force everybody to reflect on the desirability and the consistency of their choices between different options. Through these reflections and choices, identities are discursively developed. Identities are not only reflected upon during the decision making process. The reflections on these decisions also become part of the biography or development narrative. Identities thus develop through their use. Identity is a reflexive project on the trajectory of development from the past to the anticipated future. "The narrative of selfidentity has to be shaped, altered and reflexively sustained in relation to rapidly changing circumstances of social life, on a local and global scale. The individual must integrate information deriving from a diversity of mediated experiences with local involvements in such a way as to connect future projects with past experiences in a reasonably coherent fashion. Only if the person is able to develop an inner authenticity-a framework of basic trust by means of which the lifespan can be understood as a unity against the backdrop of shifting social events - can this be attained." (Giddens 1991, 215). Identities help to construct a more or less coherent path through the complexities of our risk society. They provide normative guidelines for dealing with change. They help to choose between the different opportunities and threats individuals face over time. They provide a moral compass which helps people to profit from perceived opportunities and protect themselves from perceived threats (Jaspal 2014, 5).

Identity is not limited to individuals. Collectives like local communities can also have identities grounded in accounts on sameness and difference towards others, their developmental path and the wanted or feared future development. These collective identities are constructed in identity discourses which influence individuals. These identity discourses are part of the power relations in and between communities. What constitutes power is much disputed. There are many different views on what power is and how it is used (Clegg and Haugaard 2009, 3). In this paper identity and power are linked through discourses. Local identity discourses have discursive power in a specific location at a particular time. "Power is neither defined as the power of one actor over another actor (power as a relation of subordination) nor as the power to do certain things (power as a capacity to act). Rather, power is defined as a crisscrossing field of power strategies that form and regulate the relational identities of the social actors, their conception of the world, and their range of appropriate actions. Because of its productive role in shaping meanings and identities, power is intrinsically linked to knowledge, and local forms of power-knowledge are imbedded in institutions" (Torfing 2009, 112). Identity discourses are "the more or less sedimented systems of rules, norms and meaning that condition the construction of social, political and cultural identity and action" which help us to "make sense of the world and act appropriately." (Torfing 2009, 108).

Collective identities are formed in identity discourses which interpret and guide changes, "rather than being reflected in discourse, identity is actively, ongoingly, dynamically constituted in discourse." (Benwell and Stokoe 2006, 4). Collective identity discourses are not only used to interpret the sameness and difference between different collectives. "Discourse is both constructed: people talk by deploying the resources (words, categories, common-sense ideas) available to them; and constructive: people build social worlds through descriptions and accounts" (Benwell and Stokoe 2006, 40). Identity discourses are part of power relations. The support for specific interpretations of what the identity of a local community is and how it relates to other local and regional identities, makes local identity discourses important elements in local power struggles. Local identity discourses are not only linked to territorial claims, but also to the justification of particular forms of sociospatial organisation (Benwell and Stokoe 2006, 228). Through these power struggles some identity discourses emerge as the more or less undisputed normative framework on which day-today political decision making is based. "'Constructed certitude' is a means of shoring up a clear and unified sense of identity or ideology and achieved in part by 
casting out or ignoring ambiguity or complexity" (Benwell and Stokoe 2006, 23). Identity discourses are constructed in interaction with other people and institutional structures in a specific spatial setting, this interaction makes them contradictory and changeable. "Not only do people make spaces, but also spaces make people, by constraining them but also by offering opportunities for identity construction (...) Identity is therefore a fundamentally spatial category" (Benwell and Stokoe 2006). People want to live in good places and contrast this to nearby bad places or expected and feared future threats to their place (Benwell and Stokoe 2006, 218; Cresswell 2004). Local identity discourses are rooted in normative choices, but while not everybody has the same normative frameworks they are frequently disputed and struggled over (Stones 2009). "Collective identity is not 'out there', waiting to be discovered. What is 'out there' is identity discourse on the part of political leaders, intellectuals and countless others, who engage in the process of constructing, negotiating, manipulating or affirming a response to the demand (...) for a collective image." (McSweeny 1999, 77-78). In the next section we discuss how we analysed the use of different local identity discourses in our two Dutch case studies.

\section{Measuring local identity}

We studied the use of local identities during municipal amalgamations in two Dutch municipalities. GoereeOverflakkee is a rural island with fourteen villages some thirty kilometres southwest of Rotterdam, the municipality Katwijk incorporates four villages close to the mid-sized town of Leiden and some thirty kilometres to the southwest of Amsterdam. In both municipalities the decline in employment in agriculture and fishery is offset by increased commuting to nearby Dutch cities, from which they also receive some new inhabitants. The municipality of GoereeOverflakkee was formed recently (2013) after a tumultuous merger process of four municipalities. There, in the old municipality of Goedereede, the administration and population were strongly opposed to amalgamation, despite this the merger was forced through by the central government. The other municipality, Katwijk, was formed in 2006 after a voluntary merger of three municipalities. The preservation of the different local identities was an important topic in this amalgamation. These two new municipalities were chosen in consultation with the Dutch Ministry of the Interior which commissioned this explorative research. The difference between the more peripheral rural communities on Goeree-Overflakkee and the urbanised communities in Katwijk, together with the differences between the local communities within these amalgamated municipalities, enabled us to make useful comparisons of the different use of local identities during and after municipal amalgamations (Figs. 1, 2).

Previous research frequently mention the importance of local identities in the amalgamation of municipalities in different countries (Baldersheim and Rose 2010; Mecking 2012; van Assche 2005; Boudreau and Keil 2001; Tomàs 2012; Spicer 2012; Fortin and Bédard 2003; Lightbody 1999; Keil 2000, 2002; Hulst and van Montfort 2007; Alexander 2013; Rausch 2012). These studies, however, hardly investigate the character of these local identities. Only Anssi Paasi and Kay Zimmerbauer explicitly studied the character of local identities used in the resistance against amalgamations (Zimmerbauer et al. 2012; Zimmerbauer and Paasi 2013). Most studies do not analyse how local identities are used, only that they are used and hinder amalgamation. Whereas most studies end with local identity, our study starts with local identity.

Local identities are as was discussed the previous section part of collective discourses. They are created and reproduced through discourses by stakeholders. They materialise in, for example, planning documents, newspaper reports or official websites (Paasi 1991, 2002, 2010, 2012). This research therefore started by re-constructing the existing dominant identity discourses present in policy documents, party manifesto's, local media and books about local history and daily life. This was done at different scale levels, ranging from the villages, the old-premerger municipalities (which sometimes coincide), the amalgamated municipality and its regional environment. These different identity discourses were tested and refined in open interviews with five local key actors in each municipality. These were local politicians and 


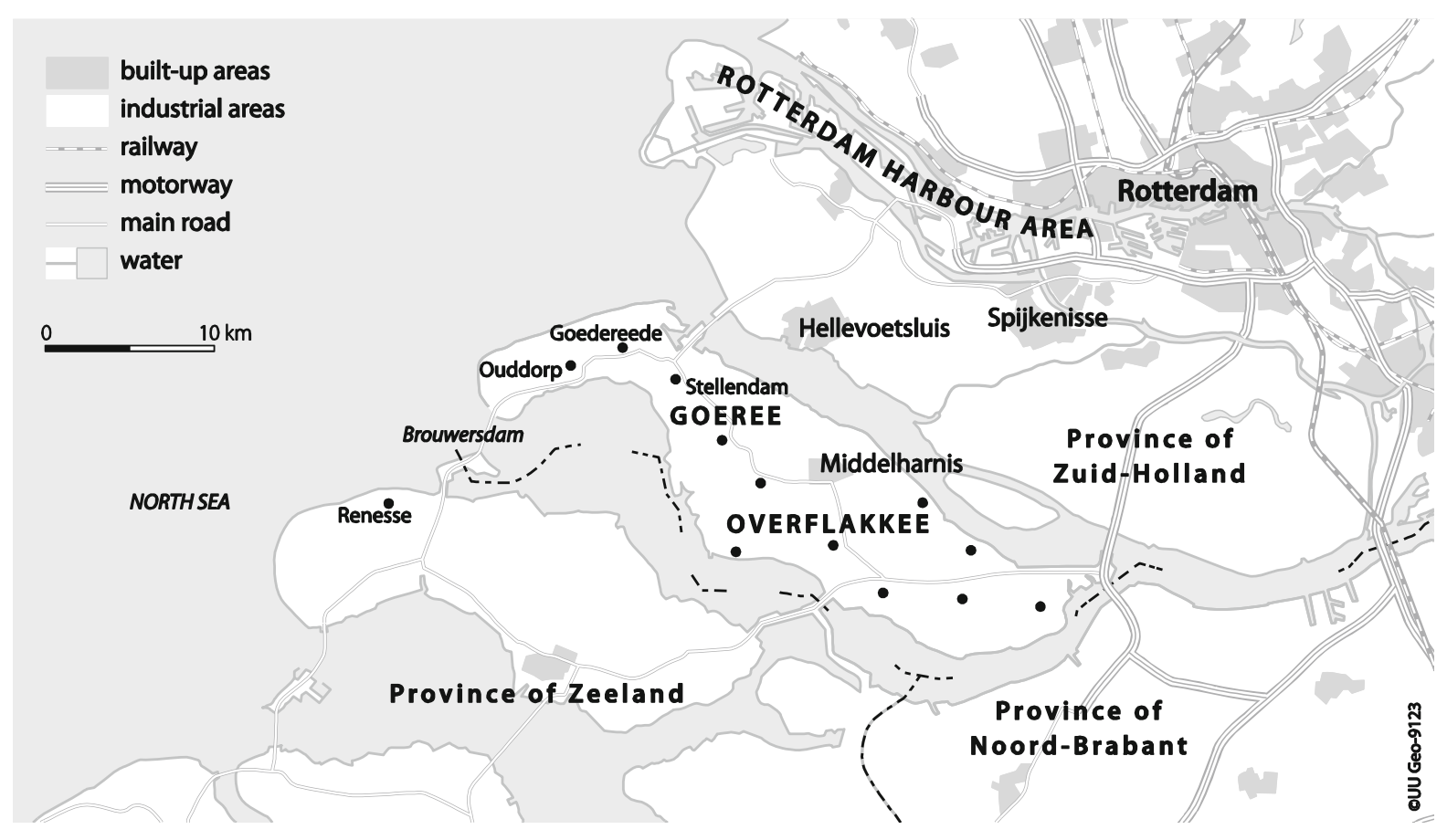

Fig. 1 Goeree-Overflakkee: an island in the Dutch delta

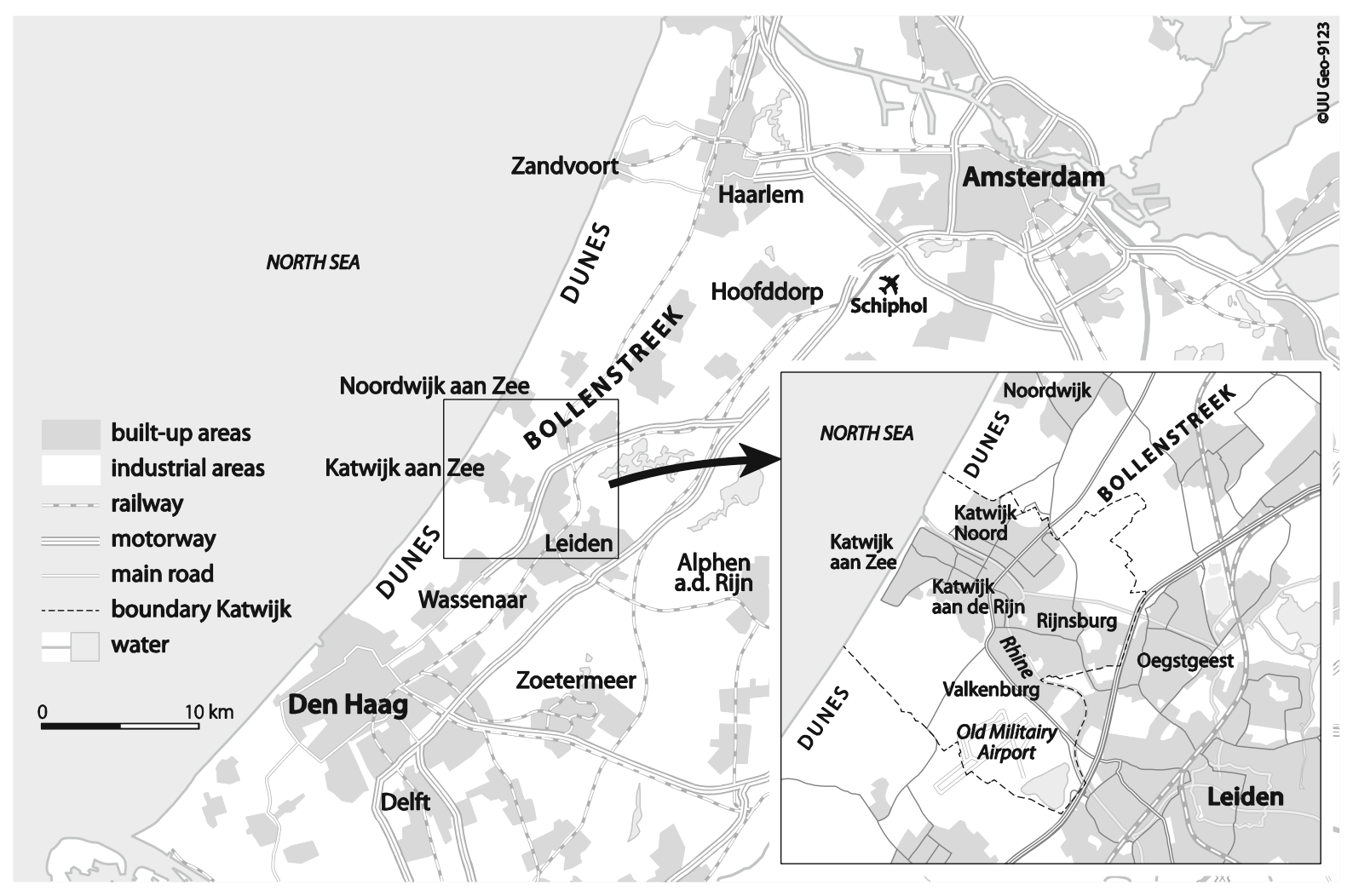

Fig. 2 Katwijk: on the edge of the Dutch urban core 
leaders of local organisations which we had identified in the study of the local sources to identify identity discourses. The different local identity discourses were the basis of a topic list we used in the semistructured interviews. The interviews always started by an open question on what characterises their local identity. Then the different identity discourses were discussed through showing pictures. Pictures are suitable tools to discuss in an open manner abstract concepts like identity (Croes et al. 2013; Holgate et al. 2012; Müller 2011). Later on, the changes in the character and use of local identity, its relation with regional identity, the conflicts related to identity and their views on the expected future changes were discussed (See for the complete list: Terlouw and Hogenstijn 2015, 165-168). Based on the analysis of the local sources and the interviews with local key actors, we identified and approached a wide range of active members within the local communities. We interviewed 58 persons in the last months of 2014. The interviewer stayed 1 week in both municipalities and in addition conducted 22 street interviews. We stopped contacting new informants when the information the interviews generated converged and no new themes or opinions were raised. The principal researcher was present during a quarter of the interviews and listened to all recorded interviews. These were transcribed in 587 pages. In a first analysis of the transcripts we identified 189 relevant topics. These were further systematised and condensed into 29 topics. Based on a further analysis of all the interview passages relevant to these topics, we wrote 29 sections, which clustered into the 7 empirical chapters of the report written for the Dutch Ministry of the Interior (Terlouw and Hogenstijn 2015).

\section{Local identity and community values}

This section starts with analysing how local identity is perceived by our interviewees. In the local population there is a widespread agreement on what characterises their local identity, but they differ widely in their valuation of this identity. This positive or negative opinion influences their behaviour towards their local identity: some want to protect it, while others want to change it. This helps to better understand the different use of local identities during municipal amalgamations which is discussed in detail in later sections.
Results

Social characteristics dominate the answers to the opening question on the general characteristics of their local identity. These characteristics were based on the daily life in their local community and were frequently linked to local events, customs, the traditional way of life and the role and character of voluntary associations. These were, on the one hand, used to differentiate their local community from others, but, on the other hand, they were frequently linked to very similar general traditional qualities like hard work, modesty, solidarity, self-reliance, adaptivity and resilience. They discussed the similarities of the different local communities within a municipality through a comparison with the bigger difference with a nearby city. "Look, we are very close to Rotterdam, but the mentality is completely different. Really totally different, incomparable. Here we work hard, we just act normal, that's already crazy enough, don't get to big for your boots, and especially don't stand out from the crowd." (Local administrator).

Local identities in general and the differences with cities in particular, are regarded as threatened and declining. "There is a tendency to guard against the outside world. Leave us alone. On the other side of the island, there is also a more traditional social structure, all sorts of things which have already disappeared a long time ago in the Randstad." (note: the Randstad is the urbanised core of the Netherlands). (Local politician). Many interviewees deplore the perceived loss of local identity. The threat of urbanisation and modernisation becomes an important part of their discourse on local identity. Some focus less on loss of local identity, but on the gain of new elements. Their local identity discourse incorporates these new elements. "What has increased, certainly in the last forty years, is the involvement with the city. Not only the material connections have improved over the years, but also the city comes this way. People settle here, live here who do not come from here. And also holiday-makers. I think that we in the meantime, very sneaky, quite substantially have changed, in our DNA. Thus the urban influence has changed our identity very much. Not that we are suddenly very different, but you notice: something is added to it." (Businessman).

The elements which characterise local identity are sometimes loosely linked by our interviewees to historical elements. History in general and the history 
of local differences and conflicts only play a secondary role. History is mostly related to the traditional differences in agricultural specialisations, social structure, village life and religion, which they use to explain local identities and their differences. For instance, businessmen operating in the municipality of Katwijk contrast the characteristics of cautious, inwardly oriented inhabitants of the old fishing village Katwijk aan Zee with the inland village of Rijnsburg: "That is because they trade originally with Germany, but now of course with the entire world. That is why they are very outwardly oriented. And impertinent. Very direct. It is not like: 'Sir, could you arrange this or that?', but: 'Darn it! What the heck is going on!' That's how these folks talk!"

Local histories or historical buildings only play a minor role in local identity discourses. Interestingly, historical buildings were only cursory linked to the past, but generated very articulate and widely divergent views on future developments in their locality. For instance, the picturesque old church on the coastline in Katwijk aan Zee (Fig. 3) is generally recognised as a symbol of this Christian fishing village. Our interviewees hardly discuss its history, nor its characteristics, nor their experiences of visiting it. They focus instead on what to do with the church square. Orthodox Christians want to keep it tranquil and empty of new elements, and perceive that it is threatened by disrespectful visiting tourists, especially on Sundays. Or, as one local administrator with a Christian background commented on the picture (Fig. 3) of the church with the new square with bronze fish sculptures: "It doesn't have to be like this! No, this is of course too much embellishment for such a respectable and frugal village. For me this is very awful ...". Others agree on the dominant orthodox Christian character of their local community, but want to change it. They think the image of the church is overused in the external communications of the municipality and stakeholders, which in their view unfortunately strengthens the stereotypical image of Katwijk aan Zee in the outside world. "Ah, the white church. That is very stereotypical Katwijk. This is really how Katwijk is promoted, with all other things, the beach, the fishing. I doubt that this is accurate."(inhabitant). Some of them want this coastal church square to be developed with sidewalk cafés and bars to attract more tourists.

This case of the old church in Katwijk aan Zee illustrates another general finding of our study. Our interviewees agree to a remarkable degree on the main characteristics of the local identity, but differed considerably in the value they attach to it. Different groups within a local community mostly agree on what

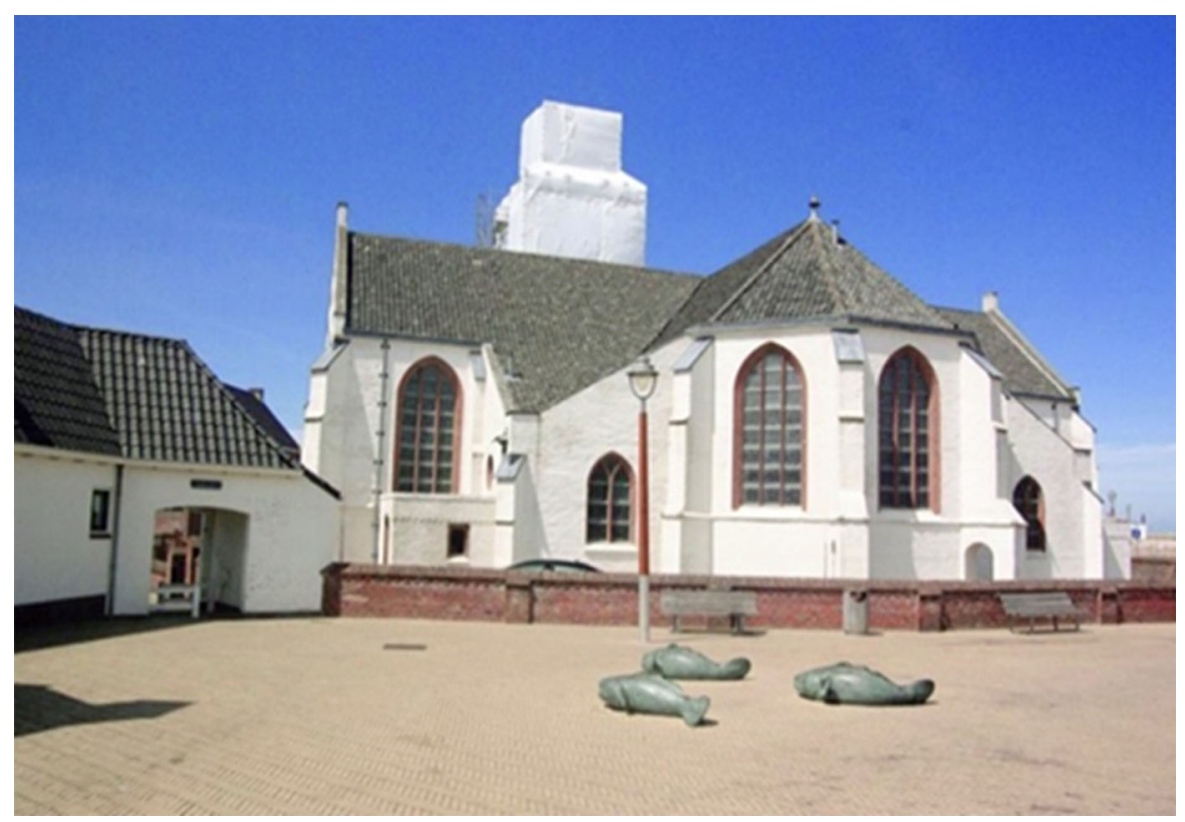

Fig. 3 The old church in Katwijk (picture made by Maarten Hogenstijn) 
characterises the identity of the local community. This cognitive consensus frequently coincides with affective disagreements on how to value this local identity, and political disputes on what action is necessary to protect or change it. This different valuation of these aspects of local identities form the basis of different local identity discourses. For instance, the general characterisation linked to the local identities in Katwijk hardly differed between elderly orthodox Protestants members of the church council and local youths of the Gothic music scene. The youths were perhaps even more aware of the local differences as they knew where in the municipality their appearance with white crosses on their black clothes elicited the most resistance. The gothic youths in Katwijk do not like the sabbatical rest on Sundays, but have learned to deal with it by cycling to the pubs in nearby towns. "Why would you change it, that would result in even more trouble with the group who dislikes it. That is in my opinion a bit useless for this. If you want to do something on a Sunday you cycle to Leiden or Noordwijk". Many of these youths also considered moving towards the nearby city of Leiden or Amsterdam.

In local communities there is widespread agreement on the cognitive content of local identities. Despite this cognitive agreement different groups can strongly disagree on how they value these characteristic which form the basis of different, but linked identity discourses. In the face of these affective discords, local communities have learned to cope with these differences in their everyday life. These established, but mostly informal ways of dealing with different valuations of local identities come to the fore when municipalities are amalgamated.

Discussion: traditionalist and modernist identity discourses

Local identity discourses not only explain the characteristics of the local community, but also suggest a developmental path. They formulate a discourse on how identities were formed in the past, how these still partly exist in the present, and how these will change in the future. The dominant discourse is of clear differences between local communities in the past, which now have become blurred through processes of social change, like urbanisation and increased mobility. The different local identities are still considered important, but the diversity is expected to further diminish or even disappear in the future. Our interviewees broadly share this discourse of still important, but declining local identities. Many fear this uniformisation of local identities and oppose it. Others welcome it and want to promote this development.

Figure 4 depicts these different perspectives of traditionalists and modernists toward changing local identities. The experience of the present generation is linked to their different visions of the distant past and future. There is widespread agreement among our interviewees that local identities were stronger in the past and will further weaken in the future. This cognitive agreed weakening of local identities is valued differently. This divergence is simplified in Fig. 4 in the opposition between traditionalists and modernists identity discourses. They diverge not only affectively on how to value this, but also conatively on how to react to this in actions. The traditionalists want to preserve and defend as much of their traditional local identity, while the modernists want to open it up and link it more with other identities at other spatial scales. This difference is rooted in a different view of the distant past. The traditionalists value the strong cohesion and collective identity in traditional villages which formed tightly knit and safe and distinct communities. Modernists agree on the tightly knit character of traditional villages, but value this differently. They object to the lack of freedom for the individual to choose its own way of life and determine its own future. The strong bonding in traditional villages is seen as smothering individual freedom. The modernist see the decline of the traditional village as part of the emancipation of the oppressed individual and the emergence of a more open modern society. The traditionalists abhor the decline of traditional village and local communities with a distinct local identity and fear its disappearance. Modernists, on the other hand, welcome the further decline of traditional villages and traditional local identities.

\section{Amalgamation and changing identity discourses}

These different discourses on changes in local identities play an important role during municipal amalgamations. Although amalgamations have only minor consequences for everyday life in the provision of public services, like passport and driving licences, 


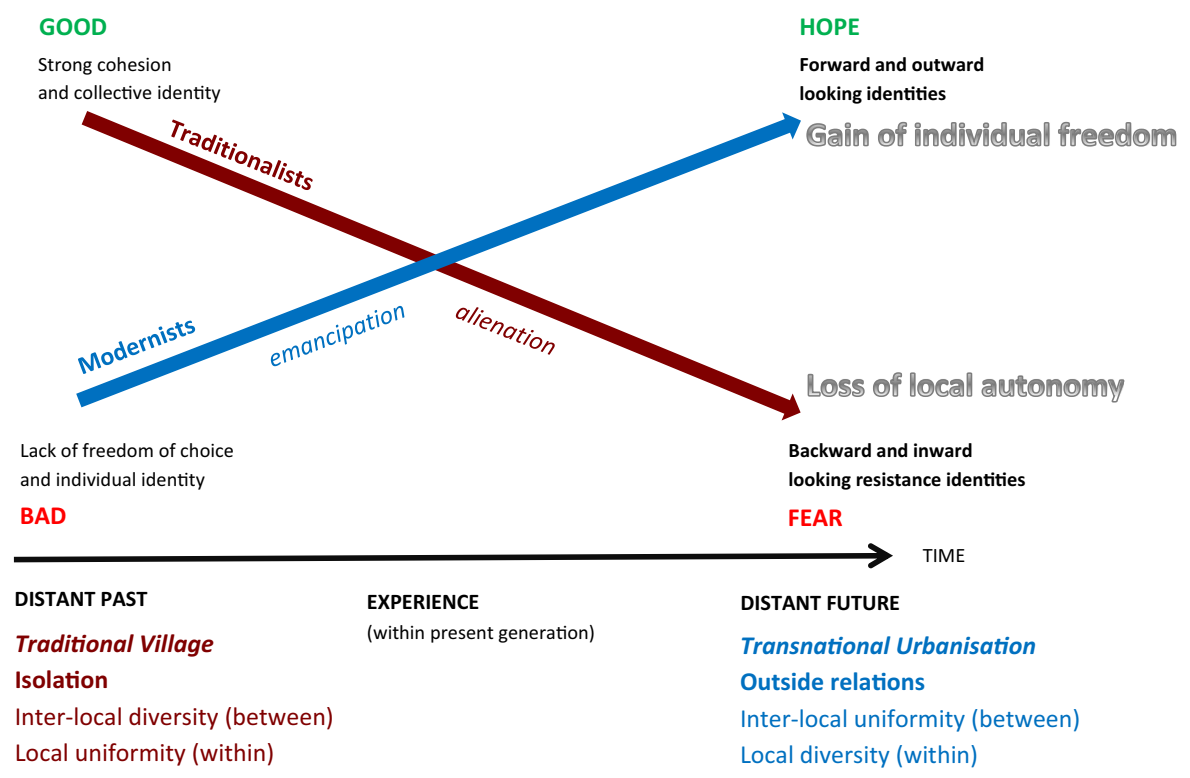

Fig. 4 Traditionalist and modernist identity discourses of fear and hope

they can fundamentally alter the political framework within which the different local identity discourses are accommodated within the municipal borders.

The changing organisation of the delivery of public services through the closing of town halls is frequently used as an argument against amalgamations. The inhabitants of the smaller municipalities whose town hall will be closed frequently use the distance to the new town hall as an argument against amalgamation. In our interviews conducted some years after the amalgamation, this argument was frequently re-evaluated. Even former opponents regard it now as a minor issue which was exaggerated during amalgamation. When asked about the legacy of the resistance to amalgamation a local politician and opponent of amalgamation comments: "It has gone silent. People who know I opposed it frequently tease me and ask me: what happened to that opposition? But people resume their everyday life, and for most nothing much has changed. Initially people were angry that they had to travel all the way to that new huge town hall. But that are peanuts, either you go by car to Middelharnis, do it over the internet or chose home delivery, that's not what it is about. It was more about culture, feelings, identity. This brings us again to the issue of identity, which involves much more than religion. It focussed on which village you live. That was what it was about. When do you need a new driving license?
Once every 10 years. You don't make a fuss about that! But the brutality of that amalgamation, which was forced down our throat, and knowing that we have been taken for a ride and that the arguments of the government are rubbish, that has disappeared. The drawing of that line wipes that out." Does this mean that the use of identity in the resistance to amalgamation is just a temporary phenomenon which disappears after amalgamation? Is it just a flash in the pan? The answer is not clear-cut and differs between amalgamations, the position of different local groups and situations which develop. For instance, the interviewee we cited above also claims that the local administration has become a Caliphate, while the now dominant Christian political parties in the amalgamated municipality prevented the yearly show of a circus in his village because it was on a Sunday.

The formation and disappearance of a local resistance identity discourse on Goeree-

Overflakkee

Let us take a closer look at the use of local identities during the amalgamation process on the isle of Goeree-Overflakkee. The resistance against amalgamation was very strong among the administration and population of Goedereede. In May 2009, 89\% polled (4825 out of a total population of 11,375 ) were 
opposed to amalgamation. But despite the opposition of the local population, the municipal council and the local administration, the Dutch government pressed ahead with the amalgamation and created the new municipality of Goeree-Overflakkee on January 1st 2013. A few months after the amalgamation, the vast majority of the population was still against amalgamation. Especially the elderly (88\%) were against. The supporters of amalgamation in contrast were predominantly young and not born in the municipality. An analysis of the reasons why people opposed amalgamation clearly showed that the feared loss of local identity was the dominant motive. A feared increase in taxation and dissatisfaction with the imposition of amalgamation by the government were far less important reasons (Jeekel et al. 2013, 30-56).

Before the amalgamation in 2013, many local stakeholders resisted amalgamation because they wanted to protect the local identities against new developments outside the control of the local communities of Ouddorp and Goedereede. This changed the character of the local identity discourses. They became more inward oriented, focussed more on their historical roots and their differences with others. This local identity discourse on the uniqueness of old municipality of Goedereede was clearly present in the documents we studied before our interviews. We therefore confronted our interviewees with a picture of one of the placards used by the opponents of amalgamation. This promoted the re-flooding of a polder in order to re-establish the situation before 1751 when it was a separate island. Almost all our interviewees reacted with embarrassment to this protest placard. "I think this is just very emotional, against their better judgement. And really when I now look at it I am ashamed ... of such emotional utterances." (Local resident). This passionate focus on differences in local identities is now regarded by most of our interviewees as not fitting the local identity which they also link to the respectful dealing with different opinions. "The resistance here was very strong. But there is also an attitude of going for it. Now we are one and we much bury the hatchet and forget it ... it is how things are, yes we are now one. And yes, that has something to do with identity. When the amalgamation was there, everyone wanted to share in the spoils and try to make the best of it. I appreciate that, and this makes us special." (Employee tourist sector).

Even the leading opponents to the amalgamation we interviewed were now more or less ashamed of the emotional resistance they had organised. Contrary to the document they produced only a few years ago in their attempts to oppose amalgamation, they now tend to deny or at least downplay the role local identities played in the protest. A local politician and former opponent of amalgamation from Ouddorp told us: "People here were against amalgamation. In a poll at the time $90 \%$ was against, but now the amalgamation is completed. The population is also law-abiding. That typifies the local identity. People loyally contribute to the formation of the new municipality. It is no use to look backwards, like it was, we never get that back. Better make the best of it and exploit the new possibilities." This and other organisers of the resistance against the amalgamation are now remarkably active in political bodies within the new municipality and participate in initiatives to promote the development of the island. Now their old municipality of Goedereede no longer exists, they try to use the new municipality of Goeree-Overflakkee to promote their local interests. They do not like to look back in anger, but want to look forward in the expectation that the new municipality will be instrumental in the promotion of a new attractive island identity discourse, which will support their local interests and identity.

The formation of the new municipality created a new positive and forward looking dynamic, which makes them look back in embarrassment to the negative emotions before the amalgamation. They seem embarrassed by the old identity discourse of the threatened local identity. The focus in their identity discourse has reversed. Their backward looking traditional local identity discourse resisting amalgamation has more or less disappeared with their old municipality. Now they promote of a forward looking regional identity discourse, which they root in their local identity and link up with similar local identities on the island. The dominant strategy which aims to protect and promote local identity and interests has shifted from the preservation of their old municipality, to the development of their island and the presentation of an attractive island identity to the outside world.

Local entrepreneurs and the formulation of a competitive island identity

The roots of this now dominant discourse on island identity go back to before the amalgamation in 2013 . In 2006, the three local branches of the cooperative 
Rabobank, the main bank financing rural entrepreneurs, merged into a cooperative for the whole island. Their management actively promoted municipal amalgamation and also produced in 2006 a vision document analysing the islands economic problems and possible solutions. They stressed the importance of promoting the island as a whole to attract investments, tourists and commuters from the Rotterdam area. Other local agricultural and touristic entrepreneurs from especially the western part of the island were also developing ideas for island promotion. These entrepreneurs linked up with proponents of municipal amalgamation who were at that time looking for a new municipal identity discourse to justify the merger and mobilise support. The local entrepreneurs took the lead in the formulation of this regional identity discourse. This has now largely been accepted by the municipal organisation and local politicians and is being communicated to the population. Or, as an active local businessman formulates: "It slowly trickles down. When you lead the way, you sometimes look back and in the rear people are unaware of who leads the way. Figuratively speaking that is. But if you communicate plentifully in many different ways, the local media, organise meetings, municipal bulletins, then it reappears (...) A kind of brainwash is necessary. But we are in only at the beginning of the Gaussian curve to adjust the identity. This is evolution not revolution. That does not suit Goeree-Overflakkee. You have to do that slowly, in small steps."

These initiatives to promote an attractive regional identity to the outside world have to deal with existing local identity discourses. As corroborated by our interviewees, elements such as close family ties, hard work ethic, resilience, self-reliance, inventiveness, solidarity and sense of community are important elements in all the different local identity discourses on the island. These characteristics of traditional local identities are combined with the attractive Dutch open landscape, the beaches of the island and their proximity to Rotterdam. These established elements of local and regional identities are combined with new policies for sustainable regional development. All these old and new elements are aligned in a new, more forward and outward oriented regional identity discourse to promote the island and mobilise support for the new municipality under the population.
Local communities on the western tip of GoereeOverflakke perceived amalgamation as a threat to their identity. Opponents emphasised their distinctiveness and its historical roots in their identity discourse. These local identity discourse was successful in mobilising the population to oppose amalgamation, but could not prevent the amalgamation imposed by the government. After the amalgamation, local stakeholders could no longer protect the local identity and interests through their old municipality. Instead, some of them joined forces with other entrepreneurs who for a long time had been advocating the municipal unification of the island in order to promote their local interests and identity. In their strategy they jumped scale from the local (old municipality) to the regional (new municipality) and now try to protect their local identity and interests through the development of a new, forward and outward looking regional identity discourse, which is still rooted in the local identities.

The regional geopolitics of Katwijk to protect local identities

In Katwijk the amalgamation of municipalities was strongly linked to the protection of local identities. The new municipality focusses on the preservation of the different established local identities and actively opposes the development of an identity discourse for the new municipality as a whole. Whereas on GoereeOverflakkee a new forward and outward looking overarching identity discourse is seen to support local identities, in Katwijk an overarching identity discourse is regarded as a threat to the different local identities. In Katwijk, local identities are used to stress the differences between local communities within the amalgamated municipality. "If you talk with a Rijnsburger he will tell you that the village of Katwijk is last place on earth he will want to live. That is the old rivalry between the communities of Katwijk and Rijnsburg. Valkenburg is still a village on its own, really a close-knit village community."

The driving force behind the voluntary amalgamation in 2006 of the old municipalities of Katwijk, Rijnsburg and Valkenburg into the new municipality of Katwijk was the fear for urban expansion. This dominated local politics in the last decades. In the $1990 \mathrm{~s}$, the central government planned to build a large new town in the rural region near Katwijk. 
Together with other rural municipalities and the associations of bulb and flower farmers, these municipalities had resisted this successfully. The construction of a regional identity discourse linking traditional rural elements with the future oriented agribusiness sector was instrumental in averting this threat for the whole region (Terlouw 2009; Terlouw and van Gorp 2014). Later a new threat emerged. The military airfield in the rural municipality of Valkenburg closed in 2006 and the central government decided that this was to be redeveloped for housing to relieve the pressures on the housing market in the Randstad, the urbanised core of the Netherlands roughly stretching from Amsterdam to Rotterdam. The neighbouring city of Leiden (122,000 inhabitants) wanted to annex Valkenburg to develop the old military airfield as a new suburb. The inhabitants and administration of the rural municipality of Valkenburg (3900 inhabitants) feared losing their local identity. Or, as one local politician formulates it: "The threat came in those days from Leiden. Valkenburg feared losing control to Leiden. We must prevent that Leiden builds its houses on the airfield. Than they will swallow us as well. That did not happen and I think they were haunted by the fear to become part of Leiden. That threat is naturally averted." Valkenburg linked up with the old municipality of Katwijk (43,000 inhabitants) who also feared the urban expansion of Leiden. Through the amalgamation with Valkenburg and Rijnsburg $(15,000$ inhabitants) they wanted to control and reduce this housing development.

The amalgamation into the new municipality of Katwijk (63,000 inhabitants) makes it big enough to resist further amalgamations. The vision document on the future of the new municipality of Katwijk reads like a declaration of independence. "The amalgamation of Katwijk, Rijnsburg and Valkenburg in the unitary municipality Katwijk is a step towards independence." (Gemeente Katwijk 2007, 13). The new municipality stresses the individuality of the three old municipalities and their will for local self-determination. Amalgamation made Katwijk a stronger player on a regional playing field dominated by mounting external pressures from urbanisation and regional cooperation. "Katwijk is like a lone wolf in the greater whole. They of course participate out of necessity, but there is no identification or natural feeling of solidarity." (Inhabitant). The administrators of Katwijk quite openly pursue a distinct regional geopolitical based on cooperating on different topics with different partners. They are afraid that cooperating on too many issues with the same partners will create a strong regional organisation, which will threaten the independence of Katwijk and the identity of its local communities. None of our interviewees identified with their region or new municipality. "Here in Katwijk you don't identify with a region. No, you only identify locally." (Inhabitant).

Local councils jealously guarding local identity and interests

This lack of identification with the amalgamated municipality Katwijk is also the result of an explicit and widely accepted municipal policy to preserve the existing local identities and the distinctive character of the different local communities. The amalgamation not only changed Katwijk's external regional geopolitical strategic position, it also created an internal political system focussing on the conservation of local identities and interests. Whereas amalgamation made Katwijk a strong player in the external regional arena, the internal position of the new municipality is relatively weak, compared to the four strong local identity discourses focussing on protecting local identities and interests towards the amalgamated municipality.

Amalgamated municipalities tend to institute village or neighbourhood councils for the old municipalities to accommodate those lamenting their loss of autonomy and identity. This is a quite common practice, not only in the Netherlands, but also in other western democracies, like Germany (Mecking 2012) and Canada (Tomàs 2012; Spicer 2012). In Katwijk the institution of neighbourhood councils were part of the agreement which led to the voluntary amalgamation of the three municipalities. "Neighbourhood councils were set up by the municipality. Neighbourhood council member are also appointed by the municipality. The goal was in response to the amalgamation to preserve the identity of the places. That's why neighbourhood councils were established. The intention was that neighbourhood councillors, who could self-apply, have strong roots in the community, based on associations, church or whatever." (Community worker). Neighbourhood councils tend to be populated by long-term residents who are very attentive of the protection of the specific identity and 
interests of their local community. A group of neighbourhood workers in Katwijk informed us on the character of the neighbourhood councils in the old municipalities Valkenburg and Rijnsburg: "They started out as action groups, as protest movements. In the beginning they were very activistic. They were more action committees than neighbourhood councils advising the municipal administration. They wanted to show Katwijk that they cannot annex Valkenburg or Rijnsburg just like that. That is reflected by the swiftness in which they attracted council members, and still they attract new members easily in contrast to other neighbourhood councils (...). When you look at individual neighbourhood council members, in my opinion, many of them become member out of a general sense of discord or some specific dispute. We try to transform that hostility into positive energy." Another community worker commented: "Every neighbourhood council wages its own battle with the municipality." Neighbourhood councils are very active in promoting the particular spatial interests of their community towards the municipality. They are very attentive of the fair distribution of investments and services of the new municipality over the different local communities. "We often hear that when the municipality has a project, it must be divided among the different places. People keep arguing that they also want what others have, and that they don't want to be disadvantaged." (Local administrator). This type of discontent with the spatial distribution of municipal investments and services was only mentioned once or twice on Goeree-Overflakkee. It was, however, a prominent theme in most of our interviews in Katwijk. Members from all different local communities in Katwijk were of the opinion that their community was disadvantaged by the new municipality. This is very similar to amalgamated rural municipalities in Australia. Every local community claims that they get less than the other local communities in the amalgamated municipality. This coincides with an increased level of distrust between neighbouring local communities after amalgamation (Alexander 2013).

\section{"Own village first"}

After municipal amalgamations, a new political community has to establish itself. For Goeree-Overflakkee, we already discussed the role of the development of a new, attractive regional identity discourse uniting the different local communities of the old municipalities. In contrast, local stakeholders in the new municipality of Katwijk shy away from the development of a strong common identity discourse. Instead they focus on the protection of the existing local identities and interests. This is partly institutionalised through the establishment of neighbourhood councils. But these are only the most explicit and visible expression of this divisive municipal politics based on the equal distribution of resources over the different local communities. This type of politics, characterised by an inhabitant as "Own village first", permeates the politics in this new municipality. While the neighbourhood councils are active and articulate local interests towards the municipality, there are many other institutions which strengthen the competition between local communities. There are many active associations in Katwijk. Compared to the rest of the Netherlands, all local communities have an active social life. This is mentioned by all our interviewees in Katwijk. But they also stress that, although almost everybody participates in local associations, they are almost exclusively member of the associations of their own community. For instance, the most active orange associations supporting the Dutch royal family are found in the municipality of Katwijk. But each local community has its own orange association organising huge local popular festivals at different dates and places. Likewise, each local community has its own, highly competitive amateur football club. Choral societies are also widespread, but very locally organised and very competitive. The important role in the municipal politics of local identities and the concern for the equal distribution of public services and investments is also entrenched in the way local political parties operate. Local communities do not have their own political party, but every political party is very aware of the importance of having politicians from each local community. "That is taken into account by the putting together of the list of candidates for the municipal elections, certainly. We did not have until late an inhabitant of Valkenburg on the list. We searched high and low, looked in the smallest corners until we found one. That was an important consideration. In the elections in Rijnsburg, I think 90-95\% of the votes went to members of that local community." (Local politician).

Before amalgamation, individual citizens could relatively easily articulate their interests and concerns 
directly to the municipal administrations. This was especially the case in the smaller municipalities, where inhabitants, local politicians and municipal officers were often very familiar with each other and their interests. A local entrepreneur observes: "The distance between the municipal administration and the citizen increases. Especially in Valkenburg. There you could, so to speak, without an appointment, walk into the office of the alderman and mayor. It was very informal there. In Rijnsburg it was largely the same. That distance is now much bigger. Everything is now decided in the far away buildings of the amalgamated municipality and we have to endure it. Look, politics represents all places. Local interest are adequately represented in the municipal council. But fewer and fewer municipal officials are linked to the local communities. These are less sensitive to local issues and identities." The local interests of citizens are now articulated in a more indirect and confrontational manner. For instance, through their local representatives in the municipal council, or in their neighbourhood council, aggrieved citizens frequently mobilise support from within their local community to force the municipality to address their interests. This strengthens the importance of local identity discourses which focus on protecting local identities against municipal policies. Instead of informal individual contacts and cooperation, local politics are more based on the confrontation between local communities, which strengthen and thicken their different local identity discourses. In the old municipalities, local identity helped to integrate local communities. In the new municipality, local identities are used in the confrontation between local communities. The development of a more confrontational local political system focussing on the fair distribution of investments and services in the amalgamated municipality goes hand in hand with the growing discontent of its citizens. This is in line with the results of other studies (Hansen 2013; Mecking 2012; Ruggiero et al. 2012; Baldersheim and Rose 2010).

Discussion: spatial institutionalisation, identities and amalgamations

This analysis of how local identities are used by stakeholders in different local communities during municipal amalgamations shows the complex relations between identities, places, people and power.
Our interviewees link local identities primarily to community values. The perceived qualities of the local communities where one lives provide important elements in the construction of local identity discourses. Most people agree on the key characteristics of local identities, but frequently appreciate these in different ways. This can result in competing local identity discourses. A key feature of all local identity discourses is that they give meaning to the relations within and between local communities. Local identity discourses interpret the relation between local communities and the outside world at different scales. Although local identity discourses focus on a municipality, these discourses also position this municipality in its spatial context. Some discourses focus on maximising independence from regional cooperation, as is the case in Katwijk, other discourses focus on attracting regional resources, like in Goeree-Overflakkee. Local identity discourses then become intertwined with regional identity discourses. On GoereeOverflakkee the new regional identity discourse explicitly uses elements from well-established local identity discourses to construct and market the region to the outside world. Local identity discourses are thus primarily rooted in the values attached to local communities, serve as a guide to evaluate future developments and focus on the relations with different scales. They are however contested and adaptive to changing circumstances.

These changing spatial identity discourses can be linked to the institutionalisation of spaces. Spatial identity discourses are not fixed in time, but are formed over time in space. Paasi $(1991,2012)$ uses four distinct, but interrelated aspects or 'shapes' to analyse this process of the institutionalisation of spaces. Through the combination of its territorial, symbolic, institutional and functional shape, an area becomes institutionalised in its own specific way. The territorial shape is the most tangible aspect. It includes the borders and the way in which these were constructed in history. Physical spatial characteristics, like landscape and land use patterns, are also part of this territorial shape. The spatial stereotypes partially based on this territorial shape and on the characteristics of its population, are a common source of the symbolic shape of an area. This shapes its spatial identity discourses. The institutionalisation of this symbolic shape of an area is also organised. Administrations and civil society constantly communicate 
this spatial identity through for instance educational institutions, policy documents and the mass media. This forms together with the political administration of its territory the institutional shape of an area. The functional shape refers to the established role of an area in larger systems. These are based on, for instance, its economic ties with neighbouring areas, or its place in the administrative hierarchy. When these four shapes interlock, they reinforce each other and generate institutionalised areas-like municipalities, regions or nations-with a clear and widely accepted spatial identity discourse. The identity discourses of institutionalised areas are based on stable communities with collective identity discourses which are passed on from generation to generation.

Bounded political spaces are not only formed, but can also disappear. Established spaces like municipalities de-institutionalise when amalgamated. Amalgamation can create new territorial borders, new political institutions and a new functional shape in a relatively short period. It takes however much more time for a symbolic shape of this new territory to become institutionalised. This lack of an established spatial identity discourse is a weak point which is frequently used by opponents who try to hang on to their old familiar spaces. This uncertainty can generate popular resistance while "communities of free an equal citizens cannot live so easily with continual adjustments of their boundaries. For these communities need to know exactly whom the administration is serving and where the limits of its authority lie. Without sharp and relatively settled boundaries the liberal project of rendering coercive authority accountable to the people who created it is impossible." (Yack 2012, 32).

Amalgamations threaten the legitimacy of municipalities. According to David Beetham, legitimacy is the result of the correspondence between the political system and social norms. This is based on a coherent, but not fixed combination of three dimensions: legality, expressed consent and justifiability. Legality refers to adherence to the established rules of acquiring and exercising power. The expressed consent of the population with the power structures in society is either mobilised, through for instance oaths and the participation in mass events, or it results from elections. Justifiability is based on social norms on the source of political authority and the purpose of government. Power "must derive from a source that is acknowledged as authoritative within society; it must serve ends that are recognised as socially necessary, and interests that are general." (Beetham 1991, 149). Justifiability is not only based on the source of the power used, but also on how successful administrations are in serving a communal interest. Legitimate political systems must adequately and efficiently serve these socially defined common interests (Beetham 1991, 70, 86). This common interest is linked to the values as expressed in the dominant identity discourses of that community.

Beetham's approach helps us to better understand the importance of local identity discourses in the legitimation of power at the local level. The legitimacy of especially smaller municipalities is increasingly threatened by the growing number of tasks they are hardly equipped to perform. The current rescaling of western states combines, therefore, the decentralisation of responsibilities to the local level, with the centralisation from the local to the regional level through their cooperation in new regions or through municipal amalgamations (Brenner 2004). Our study showed that this was the main driving force behind the amalgamation of both Katwijk and Goeree-Overflakkee. Increased efficiency and effectiveness justifies both forms of administrative restructuring, but their legitimacy is undermined on other dimensions of legitimation. Through municipal restructuring established political systems are profoundly changed, which undermines their legality, as they do not yet have established rules of acquiring and exercising power. It is also difficult to legitimise municipal restructuring through the expressions of popular consent. Although the population in the restructured municipality will elect a council, municipal restructuring is often contested by large sections of the affected population.

Amalgamation is frequently seen as an external threat to well-established local identity discourses. This was clearly the case by those who strongly opposed the amalgamation of Goedereede in GoereeOverflakkee. In general, "change undermines the capacity of places to act as arenas of self-distinctiveness, belonging, esteem, continuity and efficacy, it also potentially engenders identity threat." (Dixon et al. 2014, 274). This can lead to the development of a resistance identity discourse bonding local inhabitants by focussing on the old municipal territory, its historic roots and its difference from others (Castells 2010; 
Zimmerbauer et al. 2012; Zimmerbauer and Paasi 2013; Benwell and Stokoe 2006; Breakwell 2014; Giddens 1991). The focus of local resistance identity discourses shifts from the outside to the inside and from the future to the past. The diminishing institutional and functional shape can thus go hand in hand with a strengthening of its symbolic and territorial shape. Paradoxically, the demise of territorial autonomy can coincide with the growth of the symbolic importance of these borders. The process of spatial institutionalisation is reversed in a way. Existing discourses on the history and culture of the deinstitutionalising space are reinterpreted and refocused on the historical meaning and stability of these borders. The differences with neighbouring communities receive more emphasis and get stronger emotional overtones. Forced de-institutionalisation can thus result in the thickening of existing spatial identities discourses and their transformation into resistance identity discourses. "So the threat to the wellbeing of community members in nationalist conflicts is often perceived as a threat to the very existence of the community, not just to the material wellbeing of the members of community, but to the contingent line of cultural heritage that connects the to each other. This threat of communal death significantly raises the stakes and the level of hostility in many nationalist conflicts, especially those between small and vulnerable communities." (Yack 2012, 240)

On Goeree-Overflakkee, the initial resistance in one municipality created there wide support for a resistance identity discourse. The dominance of this local identity discourse is now succeeded by a discourse focussing on a new, forward-looking regional identity discourse, promoting the whole island to the outside world, but which is selectively rooted in the existing local identity discourses. Local identity discourses resisting amalgamation were more or less absent during the amalgamation process in Katwijk. There, the creation of an amalgamated municipality was legitimised by similar local identity discourses focussing on the preservation on local identities. Externally, the amalgamated municipality became more effective in controlling outside influences. Internally, the preservation of the different local identities hindered the development of a common identity discourse supporting a shared vision on the development of the municipality as a whole. The formation of neighbourhood councils is the most visible aspect of a local political system based on the jealously guarded fair distribution of services and investment over the different local communities. Whereas on Goeree-Overflakkee the formulation of an overarching regional identity discourse is seen by many as supporting local identities, in Katwijk the formulation of such an overlaying identity discourse is seen as a threat to the local identities.

Two different types of spatial identity discourses seem to be at work here. First of all, there are the distinct and relatively stable local identity discourses. These are the primary local identity discourses which are relatively stable and well known by the local population. Secondly, there are different ways in which communities deal with these different primary identity discourses. Within communities there is widespread cognitive agreement about what characterizes their local identity, but opinions differ on how to affectively value this and how to act upon this in daily life and local politics. Communities have developed their own informal ways to accommodate the differences between these local identity discourses over time. This specific way of dealing with the different views on local identity expressed in different local identity discourses becomes a kind of secondary local identity discourse. While primary identity discourses are more based on distinctiveness and differences, secondary identity discourses are based on dealing with these differences.

Secondary identity discourses, like any other type of identity discourse, make sense of the strained and changeable relations between elements and collectives. But, whereas primary identity discourses focus more on the distinct characteristics of local communities, secondary identity discourses focus on the relations between communities. Primary identity discourses thus focus more on places, while secondary identity discourses focus more on relations within an institutionalised political territory. Changes in the power balance between local groups and external influences like amalgamations make secondary identity discourses less stable than primary local identity discourses based on community characteristics. Whereas primary local identity discourses focus on the specific characteristics of local communities and their differences with others, secondary identity discourses are in contrast more based on accommodating these differences and the promotion of their shared interests through a more outward looking 
perspective. During a municipal amalgamation, the secondary identity discourse disappears with the old municipalities. Municipal amalgamations undermine the distinct ways in which communities have learned to live with the different visions on local identities. The disappearance of these secondary identity discourse incites renewed fears that local identities are threated. This can transform primary local identity discourses into resistance identity discourses.

Different types of secondary local identity discourses can develop over time in different amalgamated municipalities. Some of these secondary identity discourses focus primarily on the relation between local communities and the distribution of resources over the different villages. This was the case in Katwijk, where this internal distributive focus of this secondary identity discourse was combined with the protection against external urban influences to protect the rural character of its villages. In other types of secondary identity discourses, like that emerging on Goeree-Overflakkee, the focus is less on internal relations and equal distribution, but on external relations. This identity discourse focusses on promoting the development of the amalgamated municipality as a whole in relation to its environment, through the attraction of resources, people and the creation of business opportunities for local entrepreneurs to promote local development through attracting urban resources.

\section{Conclusion: three archetypes}

Three basic archetypes of the use of local identities can be distinguished: local resistance identity discourses, new regional identity discourses and divisive local identity discourses. Although these three archetypes are based on the above analysis of the case studies, they are presented here in a more abstract way.

Local resistance identity discourses

In the first archetype, local identity discourses become more inward oriented, focus more on historical roots and the differences with others; they solidify into resistance identity discourses. The feared loss of control through amalgamation frequently results in the development of local resistance identities. Local identity discourses then focus on differences and conflicts. Local resistance identities are used to oppose administrative restructuring like amalgamations. This fits quite well with how the opponents of amalgamation in the old municipality of Goedereede used local identity.

New regional identity discourses

However, local identities can also be used to generate support to collectively work for a better future through aligning with similar or complementary identity discourses. Whereas in the first archetype identity discourse becomes more inwardly focusses, in this second archetype, a more outward looking identity discourse emerges, which incorporates some elements of traditional local identity discourses, together with characteristics of the region as a whole and its position in the wider world. Sometimes a political entity such as a municipality and its secondary identity discourse is so weak that people feel that their local identity is under threat. Amalgamation or cooperation can than help to create not only a more effective and efficient organisation, but also a new and more attractive secondary identity discourse. This is usually a more forward and outward looking regional identity discourse, which can be based on a selection of characteristics of established primary local identity discourses and linked to more general policy discourses. On the island of Goeree-Overflakkee, we saw that local entrepreneurs were instrumental in the formulation of a new, thinner regional identity discourse promoting the island in the outside world and protecting and promoting local identities and interests.

\section{Divisive local identity discourses}

A third archetype of how local identities are used in local politics focusses on the protection of local identities through combining the forces of different local communities. Amalgamations can create a stronger collective shield against the outside world and local politics can actively protect the different local identities. In this archetype, identities are used differently at different scales. Externally, they collectively share a discourse of defending local identities against a mutual exterior threat like urbanisation. Internally, local identities are protected and form the basis of a distributive policies. These relation between 
local communities and the distribution of resources over the local communities become part of their secondary identity discourse. In Katwijk, this divisive use of local identities is clearly recognisable. The internal distributive focus of the secondary identity discourse was combined with the protection of the rural character of its villages against external urban influences.

Acknowledgements I thank Maarten Hogenstijn who conducted the interviews, our contacts at the Dutch Ministry of the Interior, Ruud Smeets, Rick Brouwer, Merel de Groot and Tobias Kwakkelstein, all the persons interviewed in Katwijk and Goeree-Overflakkee, and the referees and editor of this journal.

\section{Compliance with ethical standards}

Ethical approval statements This paper is based on research funded by the Dutch Ministry of the Interior. Ethical approval: "All procedures performed in studies involving human participants were in accordance with the ethical standards of the institutional and/or national research committee and with the 1964 Helsinki declaration and its later amendments or comparable ethical standards." All our interviewees were informed of the purpose of this research and agreed on using the transcribed interviews anonymously.

Open Access This article is distributed under the terms of the Creative Commons Attribution 4.0 International License (http:// creativecommons.org/licenses/by/4.0/), which permits unrestricted use, distribution, and reproduction in any medium, provided you give appropriate credit to the original author(s) and the source, provide a link to the Creative Commons license, and indicate if changes were made.

\section{References}

Alexander, D. (2013). Crossing boundaries: Action networks, amalgamation and inter-community trust in a small rural shire. Local Government Studies, 39(4), 463-487.

Baldersheim, H., \& Rose, L. E. (Eds.). (2010). Territorial choice: The politics of boundaries and borders. New York: Palgrave.

Beetham, D. (1991). The legitimation of power. Basingstoke: Macmillan.

Benwell, B., \& Stokoe, E. (2006). Discourse and identity. Edinburgh: Edinburgh University Press.

Boudreau, J., \& Keil, R. (2001). Seceding from responsibility? Secession movements in Los Angeles. Urban Studies, 38(10), 1701-1731.

Breakwell, G. M. (2014). Identity and social representations. In R. Jaspal \& G. M. Breakwell (Eds.), Identity process theory: Identity, social action and social change (pp. 118-134). Cambridge: Cambridge University Press.
Brenner, N. (2004). New state spaces: Urban governance and the rescaling of statehood. Oxford: Oxford University Press.

BZK. (2013). Bestuur in samenhang. Den Haag: Ministerie van Binnenlandse Zaken en Koninkrijksrelaties.

Castells, M. (2010). The power of identity (2nd ed.). Chichester: Wiley-Blackwell.

Cresswell, T. (2004). Place: A short introduction. Oxford: Blackwell.

Croes, R., Lee, S. H., \& Olson, E. D. (2013). Authenticity in tourism in small island destinations: A local perspective. Journal of Tourism and Cultural Change, 11(1-2), 1-20.

Dixon, J., Durrheim, K., \& Di Masso, A. (2014). Places, identities and geopolitical change. In R. Jaspal \& G. M. Breakwell (Eds.), Identity process theory: Identity, social action and social change (pp. 270-294). Cambridge: Cambridge University Press.

Fortin, A., \& Bédard, M. (2003). Citadins et banlieusards. Représentations, pratiques et identités. Canadian Journal of Urban Research, 12(1), 124-142.

Gemeente Katwijk. (2007). BSV Katwijk. Een zee aan mogelijkheden. Brede Structuurvisie 2007-2020. Katwijk: Gemeente Katwijk.

Giddens, A. (1991). Modernity and self-identity: Self and society in the late modern age. Cambridge: Polity.

Hansen, S. W. (2013). Polity size and local political trust: A Quasi-experiment using municipal mergers in Denmark. Scandinavian Political Studies, 36(1), 43-66.

Haugaard, M., \& Clegg, S. R. (2009). Introduction: Why is power the central concept in the social sciences? In M. Haugaard \& S. R. Clegg (Eds.), The Sage handbook of power (pp. 1-24). London: The Sage.

Holgate, J., Keles, J., \& Kumarappan, L. (2012). Visualizing 'community': An experiment in participatory photography among Kurdish diasporic workers in London. The Sociological Review, 60(2), 312-332.

Hulst, R., \& van Montfort, A. (2007). Inter-municipal cooperation in Europe. Dordrecht: Springer.

Jaspal, R. (2014). Social psychological debates about identity. In R. Jaspal \& G. M. Breakwell (Eds.), Identity process theory: Identity, social action and social change (pp. 3-19). Cambridge: Cambridge University Press.

Jeekel, P., Leth, D. O. de Nijhout, M., \& Snoeker, B. (2013). Een onderzoek naar verzet tegen gemeentelijke herindelingen. Utrecht: Honours leeronderzoek SGPL.

Keil, R. (2000). Governance restructuring in Los Angeles and Toronto: Amalgamation or secession? International Journal of Urban and Regional Research, 24(4), 758-781.

Keil, R. (2002). "Common-sense" neoliberalism: Progressive conservative urbanism in Toronto, Canada. Antipode, 34(3), 578-601.

Lightbody, J. (1999). Canada's seraglio cities: Political barriers to regional governance. Canadian Journal of Sociology, 24(2), 175-191.

McSweeny, B. (1999). Security, identity and interests. Cambridge: Cambridge University Press.

Mecking, S. (2012). Bürgerwille und Gebietsreform: Demokratieentwicklung und Neuordnung von Staat und Gesellschaft in Nordrhein-Westfalen 1965-2000. München: Oldenbourg Verlag. 
Müller, F. (2011). Urban alchemy: Performing urban cosmopolitanism in London and Amsterdam. Urban Studies, 48(16), 3415-3431.

Paasi, A. (1991). Deconstructing regions: Notes on the scales of spatial life. Environment and Planning A, 23(2), 239-254.

Paasi, A. (2002). Bounded spaces in the mobile world: Deconstructing 'regional identity'. Tijdschrift voor Economische en Sociale Geografie, 93(2), 137-148.

Paasi, A. (2010). Commentary: Regions are social constructs, but who or what constructs them? Agency in question, Environment and Planning A, 42(10), 2296-2301.

Paasi, A. (2012). Regional planning and the mobilization of 'regional identity': From bounded spaces to relational complexity. Regional Studies, 47(8), 1206-1219.

Rausch, A. S. (2012). A framework for Japan's new municipal reality: Assessing the Heisei gappei mergers. Japan Forum, 24(2), 185-204.

Ruggiero, P., Monfardini, P., \& Mussari, R. (2012). Territorial boundaries as limits: A Foucauldian analysis of the agglomeration of municipalities. International Journal of Public Administration, 35(7), 492-506.

Spicer, Z. (2012). Post-amalgamation politics. Canadian Journal of Urban Research, 21(2), 90-111.

Stones, R. (2009). Power and structuration theory. In M. Haugaard \& S. R. Clegg (Eds.), The Sage handbook of power (pp. 89-107). London: Sage.

Terlouw, K. (2009). Rescaling regional identities: Communicating thick and thin regional identities. Studies in Ethnicity and Nationalism, 9(3), 452-464.

Terlouw, K., \& Hogenstijn, M. (2015) "Eerst waren we gewoon wij en nu is het wij en zij": gebruik slijtage en vernieuwing van regionale identiteiten. Den Haag: Ministerie van Binnenlandse Zaken en Koninkrijksrelaties. http://www. rijksoverheid.nl/bestanden/documenten-en-publicaties/ rapporten/2015/05/01/onderzoeksrapport-over-lokale-enregionale-identiteiten/eerst-waren-we-gewoon-wijterlouw-hogenstijn-2015.pdf.

Terlouw, K., \& Van Gorp, B. (2014). Layering spatial identities: The identity discourses of new regions. Environment and Planning A, 46(4), 852-866.

Tomàs, M. (2012). Exploring the metropolitan trap. International Journal of Urban and Regional Research, 36(3), 554-567.

Torfing, J. (2009). Power and discourse: Towards an antifoundationalist concept of power. In M. Haugaard \& S. R. Clegg (Eds.), The Sage handbook of power (pp. 108-124). London: Sage.

Van Assche, D. (2005). Lokale politiek als katalysator van vertrouwen: binnengemeentelijke decentralisatie in Antwerpen. Brugge: Vanden Broele.

Verhaeghe, P. (2014). What about me? The struggle for identity in a market-based society. Scribe: Melbourne.

Yack, B. (2012). Nationalism and the moral psychology of community. Chicago: University of Chicago Press.

Zimmerbauer, K., \& Paasi, A. (2013). When old and new regionalism collide: Deinstitutionalization of regions and resistance identity in municipality amalgamations. Journal of Rural Studies, 30(2), 31-40.

Zimmerbauer, K., Suutari, T., \& Saartenoja, A. (2012). Resistance to the deinstitutionalization of a region: Borders, identity and activism in a municipality merger. Geoforum, 43(6), 1065-1075. 